\title{
STRATEGI PENINGKATAN KINERJA GABUNGAN PERKUMPULAN PETANI PEMAKAI AIR (GP3A) DI KABUPATEN BOGOR
}

\author{
Performance Improvement Strategy for Water User Associations Federation (WUAF) \\ in Bogor Regency \\ Bobby Wahyudi ${ }^{1}$, Yusman Syaukat ${ }^{2}$, Lala M. Kolopaking ${ }^{3}$ \\ ${ }^{1}$ Staff Dinas Bina Marga dan Pengairan Kabupaten Bogor. E-mail: bobby_w76@yahoo.com \\ 2 Staff Pengajar Departemen Ekonomi Sumberdaya dan Lingkungan, Fakultas Ekonomi dan Manajemen. \\ Institut Pertanian Bogor. E-mail: ysyaukat@gmail.com \\ ${ }^{3}$ Staff Pengajar Departemen Sains Komunikasi Pembangunan, Fakultas Ekologi Manusia. \\ Institut Pertanian Bogor. E-mail: lalakolopaking@gmail.com
}

\begin{abstract}
This study aimed to obtain Current overview about the implementation of program WISMP in Bogor Regency as study for local government policy-making, by identifying the internal and external factors and formulating strategies for improving the performance of Water User Associations Federation (WUAF) in Bogor Regency. The study was conducted in Bogor Regency, by using primary and secondary data. Problems in this study is how the performance of Water User Associations Federation (WUAF) as Program recipients WISMP I in the first five years has been as planned, How are the WUAF conditions of DI that receiving and DI did not receive WISMP I program in Bogor Regency. The method of analysis used is the Importance Performance Analisys (IPA), Farmers' Income Analysis, SWOT Analysis (Strangths-Weaknesses-Opportunities-Threats) Analysis of Quantitative Strategies and Planning Matrix (QSPM). Results Importance Performance Analisys (IPA) shows there are 6 variables in quadrant $A$ (level of performance), 6 variables in quadrant B (maintain performance), 6 variables in quadrant $C$ (low priority) and 2 variables in quadrant $D$ (likely exaggerated). Based on the results of the study, priority strategies for improving the Water User Associations Federation (WUAF) in Bogor Regency is based on the level of performance and quality aspects of performance WUAF in Bogor Regency by $30 \%$ is considered to be enhanced performance. Emphasis strategy by utilizing external opportunities to existing internal weaknesses (WO strategy). The strategy is the first priority is to program management plan participatory irrigation network for increased production and increase the welfare of farmers in Bogor Regency RPJMD with TAS value 8.34.
\end{abstract}

Keywords: Performance, Strategy, WISMP, WUAF

\begin{abstract}
ABSTRAK
Penelitian ini dimaksudkan untuk memperoleh gambaran aktual tentang pelaksanaan program WISMP di Kabupaten Bogor, sebagai bahan pembelajaran untuk pengambilan kebijakan selanjutnya bagi pemerintah daerah, dengan cara mengidentifikasi faktor-faktor internal - ekternal dan merumuskan strategi peningkatan kinerja Gabungan Perkumpulan Petani Pemakai Air (GP3A) di Kabupaten Bogor. Penelitian dilakukan di Kabupaten Bogor, dengan mengunakan data primer dan sekunder. Perumusan masalah dalam kajian ini yaitu bagaimanakah kinerja Gabungan Perkumpulan Petani Pemakai Air (GP3A) penerima Program WISMP I pada lima tahun pertama ini sudah sesuai dengan yang direncanakan, Bagaimanakah kondisi GP3A pada DI yang menerima dan DI tidak menerima Program WISMP I di Kabupaten Bogor. Metoda analisis yang digunakan adalah Importance Performance Analisys (IPA), Analisis Pendapatan Petani, Analisis SWOT (Strangths-Weaknesses-OpportunitiesThreats) dan Analisis Quantitative Strategies Planning Matrix (QSPM). Hasil Importance Performance Analisys (IPA) menunjukan ada 6 variabel di kuadran A (tingkat kinerja), 6 variabel di kuadran B (pertahankan kinerja), 6 variabel di kuadran $\mathrm{C}$ (prioritas rendah) dan 2 variabel di kuadran $\mathrm{D}$ (cenderung berlebihan). Berdasarkan hasil kajian, prioritas strategi peningkatan kinerja Gabungan Perkumpulan Petani Pemakai Air (GP3A) di Kabupaten Bogor didasarkan pada aspek tingkat kinerja dan kualitas


kinerja GP3A di Kabupaten Bogor sebesar 30\% yang dinilai harus ditingkatkan kinerjanya. Penekanan strategi dengan memanfaatkan peluang eksternal terhadap kelemahan internal yang ada (Strategi WO). Strategi yang menjadi prioritas pertama adalah memprogramkan rencana pengelolaan jaringan irigasi secara partisipatif untuk peningkatan produksi dan peningkatan kesejahteraan petani dalam RPJMD Kabupaten Bogor dengan nilai TAS 8,34.

Kata Kunci : GP3A, Kinerja, Strategi, WISMP

\section{PENDAHULUAN}

\section{Latar Belakang}

Amanat yang terdapat dalam PP 20/2006 adalah pembagian wewenang pengelolaan sistem irigasi, penguatan kelembagaan pengelolaan irigasi, dan penyelenggaraan pengelolaan irigasi secara partisipatif. Berdasarkan luasannya pengelolaan daerah irigasi (DI) dibagi menjadi 3 (tiga) kewenangan meliputi: $\geq$ 3.000 ha menjadi tanggung jawab Pemerintah Pusat, 3.000 ha -1.000 ha menjadi tanggung jawab pemerintah Provinsi, dan $<1.000$ ha menjadi tanggung jawab pemerintah Kabupaten. Pengelolaan di jaringan primer dan sekunder menjadi tanggung jawab pemerintah, petani bertangung jawab terhadap pengelolaan di jaringan tersier. Kelembagaan pengelolaan irigasi meliputi lembaga atau dinas yang membidangi irigasi, Komisi Irigasi, dan P3A/GP3A. Adapun partisipasi masyarakat petani dalam pengembangan dan pengelolaan sistem irigasi diwujudkan mulai dari pemikiran awal, pengambilan keputusan, dan pelaksanaan kegiatan dalam pembangunan, peningkatan, operasi, pemeliharaan, dan rehabilitasi. Partsipasinya dapat berupa sumbangan pemikiran, gagasan, waktu, tenaga, material, dan dana.

Sejak tahun 1997, Pemerintah Pusat memulai program untuk reformasi kelembagaan untuk mewujudkan penyelenggaraan pemerintah yang efektif, efisien, akuntabel, dan berkelanjutan. Tujuannya adalah peningkatan peran serta (partisipasi) masyarakat dalam mengelola fasilitas umum dan desentralisasi seperti

\footnotetext{
${ }^{1}$ Preparation of Program Implementation Plan - Phase I, 2004 Bobby Wahyudi, Yusman Syaukat, dan Lala M Kolopaking
}

yang diamanatkan UU Nomor 32 Tahun 2004 tentang Pemerintah Daerah dan UU Nomor 33 Tahun 2004 tentang Perimbangan Keuangan Pusat dan Daerah ${ }^{1}$. Sejalan dengan program Pemerintah tersebut Bank Dunia yang telah lama mengikuti perkembangan perubahan peraturan yang ada di Indonesia menyediakan dana untuk membantu Pemerintah menerapkan peraturanperaturan tersebut. Bank Dunia telah terlibat dalam program JWIMP (Java Irrigation Improvement and Water Management Project 1992-2002) dan WATSAL (Water Resources Sector Adjustment Loan 1999-2003) yang merupakan program yang membantu pelaksanaan reformasi pengelolaan irigasi dan penguatan kelembagaan $\mathrm{P} 3 \mathrm{~A} / \mathrm{GP} 3 \mathrm{~A}$ yang dipusatkan di Pulau Jawa. Program tersebut diikuti dengan IWIRIP (20012004) dengan tujuan yang sama yang dilaksanakan di luar Pulau Jawa. Melihat dari pengalaman program-program tersebut Pemerintah bekerja sama dengan Bank Dunia meluncurkan program WISMP (Water Resources and Irrigation Sector Management Program).

Tujuan khusus untuk sektor pengelolaan jaringan irigasi adalah untuk memperjelas pembagian kewenangan antar tingkat pemerintahan, mendorong kerjasama antar pemerintah daerah dan antara pemerintah daerah dengan pusat, menata kelembagaan pemerintah daerah dan pusat, meningkatkan kualitas aparatur pemerintah, meningkatkan kapasitas keuangan pemerintah daerah khususnya di bidang pengelolaan sumber daya air serta rehabilitasi prasarana sungai prioritas dan jaringan irigasi. Peserta WISMP adalah 
Provinsi dan Kabupaten yang pernah mengikuti program JWIMP dan IWIRIP (Indonesia Water Resources and Irrigation Reform Implementation Program) mengingat WISMP merupakan program lanjutan dari program-program tersebut. Provinsi tersebut adalah Banten, Jawa Barat, Jawa Tengah, DI Yogyakarta, Jawa Timur, Aceh, Sumatera Utara, Sumatera Barat, Sumatera Selatan, Lampung, Nusa Tenggara Timur, Sulawesi Selatan, dan Sulawesi Tengah. Program WISMP secara resmi dimulai pada tahun 2006.

\section{Perumusan Masalah}

Kegiatan WISMP di Kabupaten Bogor dilaksanakan pihak yang terkait pengelolaan irigasi secara partisipatif yaitu Bappeda, DBMP, dan Distanhut. Kegiatan yang dilaksanakan meliputi kegiatan Peningkatan Kapasitas Pemerintahan dan P3A/GP3A, Peningkatan Kapasitas Dinas SDA Kabupaten, Perbaikan Pekerjaan Irigasi Selektif, dan Pendukung Pertanian Beririgasi, Setiap tahunnya para pihak menyusun rencana kegiatan berdasarkan kesepakatan bersama dan dilaksanakan secara paralel sesuai pembagian peran yang ditetapkan. Kegiatan-kegiatan yang dilaksanakan masing-masing instansi pada dasarnya ditujukan untuk mencapai tujuan akhir peningkatan kesejahteraan petani melalui peningkatan pendapatan petani. Sehingga pada awal evaluasi perlu dilihat dan dianalisa Bagaimanakah kinerja Gabungan Perkumpulan Petani Pemakai Air (GP3A) penerima Program WISMP I pada lima tahun pertama ini sudah sesuai dengan yang direncanakan?.

Penguatan kapasitas (pemberdayaan) kelembagaan pengelolaan irigasi mempunyai peran sangat penting dalam usaha melaksanakan keberlanjutan pengelolaan irigasi secara partisipatif. Mengingat kelembagaan pengelolaan irigasi bersifat lintas instansi dan melibatkan beberapa organisasi, maka sangat penting untuk merumuskan Strategi Peningkatan Kinerja Gabungan Perkumpulan Petani Pemakai Air (GP3A), sehingga dapat diambil langkah-

Bobby Wahyudi, Yusman Syaukat, dan Lala M Kolopaking langkah strategis yang tepat dalam pengembangan program tersebut oleh Pemerintah Kabupaten Bogor terutama untuk mendukung keberlanjutan pelaksanaan pengelolaan irigasi secara partisipatif.

\section{Tujuan Penelitian}

Berdasarkan perumusan masalah di atas, secara spesifik tujuan penelitian ini adalah

1. Menganalisis kinerja GP3A penerima program WISMP dan bukan penerima program WISMP.

2. Merumuskan Strategi Peningkatan Kinerja Gabungan Perkumpulan Petani Pemakai Air (GP3A).

\section{Ruang Lingkup Penelitian}

Secara umum Program WISMP terdiri dari beberapa tahapan pelaksanaan kegiatan seperti kegiatan penyerahan kewenangan, pembinaan, pelatihan, motivasi, fasilitasi, bimbingan teknis, pendampingan, kerjasama pengelolaan dan audit pengelolaan irigasi. Penelitian ini difokuskan untuk mengkaji pelaksanaan program WISMP APL Tahap I yang telah dilaksanakan pada kurun waktu tahun 2006 sampai dengan tahun 2010, dan pengambilan data sampel untuk penelitian ini adalah pada akhir pelaksanaan APL I yaitu dari tahun 2010 hingga tahun 2013. Supaya penelitian dapat dilakukan secara lebih mendalam, maka tidak semua indikator kinerja kegiatan Program WISMP ini diukur. Pengukuran dibatasi pada evaluasi dampak kegiatan Program WISMP terhadap kinerja GP3A penerima manfaat. Dan membatasi daerah penelitian pada GP3A Mitra Tani di Desa Karehkel dan GP3A Leubak di Desa Leuwimekar Kecamatan Leuwiliang.

\section{Kajian Empiris Terdahulu}

Beberapa studi terkait dengan
peningkatan kinerja Gabungan
Perkumpulan Petani Pemakai Air (GP3A),
diantaranya seperti yang dilakukan oleh
Caesarion (2011), melakukan penelitian
Strategi Peningkatan Kinerja Gabungan
Perkumpulan Petani Pemakai Air (GP3A)
Di Kabupatan Bogor


mengenai efektivitas program PUAP terhadap kinerja usaha kecil dengan menggunakan metode statistik analisis regresi linier berganda. Variabel yang digunakan adalah kesesuaian perencanaan dengan pelaksanaan kegiatan usaha tani; pengembangan agribisnis perdesaan; pengembangan usaha mikro; dan peran pendampingan. Hasil analisis menunjukkan bahwa setelah adanya bantuan program PUAP kinerja usaha kecil pertanian menjadi lebih efektif.

1) Santosa et al. (2003) pendekatan penelitian evaluasi dampak yang dilakukan adalah dengan menggunakan metode ESCAP (Economic and Social Commision for Asian and Pacific) yakni dengan menilai beberapa indikator seperti peningkatan pendapatan, pengurangan kemiskinan, efisiensi penyaluran program dan kelangsungan dana. Program penanggulangan kemiskinan yang dievaluasi meliputi program Inpres Desa Tertinggal (IDT), Program Pengembangan Kecamatan (PPK), dan Program Penanggulangan Kemiskinan Perkotaan (P2KP), yang ketiganya dikategorikan sebagai Program Kerja Mandiri dan Proyek Pembangunan Fisik dalam Program PPK yang dikategorikan sebagai Program Padat Karya. Hasil kesimpulan dari penelitiannya adalah bahwa pelaksanaan program pinjaman bergulir lebih berhasil dalam menanggulangi kemiskinan di wilayah sampel dibanding dengan program padat karya.

2) Ravallion et al. (2005) melakukan evaluasi dampak pelaksanaan Program Trajabar di Argentina. Penelitian ini bertujuan untuk melihat evaluasi dampak (Impact Evaluation) tentang manfaat yang diperoleh orang miskin dari pasar tenaga kerja. Metode yang digunakan dalam mengukur evaluasi dampak ini adalah Selisih-dalam selisih (Difference-in-difference). Evaluasi dampak yang dilakukan menyangkut aspek tingkat pendapatan, tingkat

Bobby Wahyudi, Yusman Syaukat, dan Lala M Kolopaking partisipasi orang miskin, dan tingkat pengangguran. Langkah yang dilakukan adalah menghitung perubahan tingkat pendapatan orang miskin yang mengikuti program Trajabar sebelum intervensi program (baseline) dan setelah adanya intervensi. Selain itu dilakukan juga proses netting-out dengan membentuk Kelompok Kontrol sehingga diperoleh besar dampak yang ditimbulkan dari program tersebut.

3) Chandra et al. (2010) melakukan pendekatan evaluasi dampak pelaksanaan program penanggulangan kemiskinan dengan menggunakan evaluasi kualitatif yakni mengukur penilaian baik, sedang, dan buruk dari suatu program dengan menitikberatkan pada proses pelaksanaan program mulai dari input, proses, output, outcome, dan benefit.

4) Akbar (2011) melakukan penelitian mengenai Strategi Keberlanjutan Program PUAP di Kabupaten Karawang dengan menganalisis pada kinerja gapoktan penerima PUAP dengan metode analisis yang digunakan adalah Importance Performance Analysis (IPA), Analisis Pendapatan Petani, Evaluasi Faktor Internal (IFE- Internal Factor Evaluation), Evaluasi Faktor Ekxternal (EFE- Eksternal Factor Evaluation), Analisis SWOT (StrengthsWeaknesses-Opportunities-Threats) dan Analisis QSPM (Quantitative Strategies Planning Matrix). Hasil analisis dan kajiannya memperioritaskan strategi keberlanjutan program PUAP didasarkan pada aspek peningkatan kualitas dan kinerja Gapoktan di Kabupaten Karawang.

\section{Kerangka Pemikiran}

Penilaian kinerja GP3A Mitra Tani dianalisis dengan menggunakan metode Importance Performance Analysis. Data yang dikumpulkan kemudian diolah dan dianalisis sehingga mampu memberikan gambaran dan penjelasan terhadap

Strategi Peningkatan Kinerja Gabungan Perkumpulan Petani Pemakai Air (GP3A) Di Kabupatan Bogor 
permasalahan dalam penelitian ini. Dalam memperoleh strategi yang diinginkan untuk Pengelolaan Irigasi Partisipatif di Kabupaten Bogor, selanjutnya dengan analisa SWOT dilakukan pemilahan mana yang menjadi kekuatan, kelemahan, peluang dan ancaman nantinya diharapkan mampu memetakan kondisi yang ada, sehingga dapat dibuat strategi kebijakan yang terdiri dari strategi SO, strategi ST, strategi WO dan strategi WT.

Hasil strategi yang dilakukan dari analisis SWOT akan didapatkan beberapa alternatif strategi pengembangan Pengelolaan Irigasi Partisipatif di Kabupaten Bogor. Kemudian dilakukan penyususnan matriks Quantitatif Strategy Planing (QSP) untuk mendapatkan strategi pengembangan yang di inginkan. Kerangka pemikiran kajian tentang Evaluasi Pelaksanaan Program Water Resources and Irrigation Project (WISMP) Terhadap Keberlanjutan Pengelolaan Irigasi Partisipatif di Kabupaten Bogor disajikan dalam Gambar 3.1.

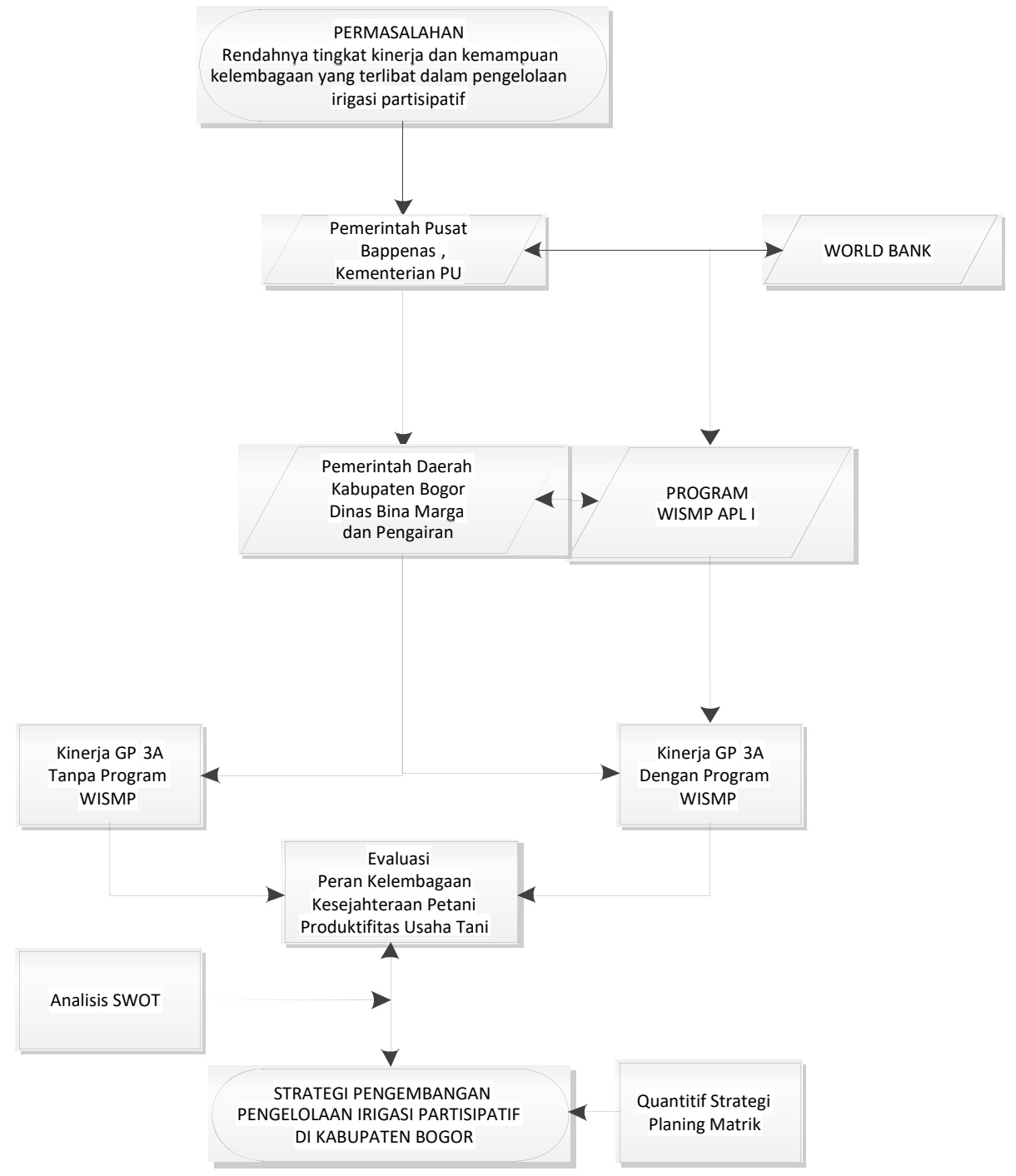

Gambar 1. Bagan Alur Kerangka Pemikiran 


\section{Lokasi dan Waktu Penelitian}

Penelitian secara umum ini dilaksanakan di Kabupaten Bogor, khususnya pada Daerah Irigasi yang terdapat di Kecamatan Leuwiliang, yang sudah memiliki pengurus GP3A, sebanyak 1 Daerah Irigasi dalam masa periode pelaksanaan program WISMP I (2005-2010), dan 1 Daerah Irigasi yang belum menerima program WISMP 1. Pengambilan sampel dilaksanakan sejak bulan Juli sampai dengan bulan September 2013, dalam dua priode, priode kedua selama 30 hari, merupakan priode evaluasi dan melengkapi kekurangan data yang telah diperoleh pada priode pertama.

\section{Metode Pengumpulan Data}

Dilihat dari sumber datanya, pengumpulan data dapat menggunakan data primer dan data sekunder (Kuncoro, 2003). Data sekunder yaitu data yang telah dikumpulkan oleh lembaga pengumpul data dan dipublikasikan kepada masyarakat pengguna data. Data primer adalah data yang diperoleh dengan survei lapangan yang menggunakan semua metode pengumpulan data original (Kuncoro, 2003). Data primer dalam penelitian ini dikumpulkan melalui kuesioner yang selengkapnya disajikan dalam lampiran yang ditujukan kepada GP3A penerima manfaat dan
GP3A bukan penerima manfaat. Selain kuesioner, untuk memperdalam pemahaman terhadap masalah yang sedang diteliti, penulis juga melakukan wawancara (interview) pada pihak-pihak yang terkait dengan pelaksanaan program WISMP di GP3A, antara lain dengan Kepala GP3A dan pengurusnya, pendamping/penyuluh yang mendampingi GP3A tersebut.

\section{Metoda Analisis}

Analisis deskriptif dilakukan untuk menjelaskan gambaran umum mengenai pelaksanaan pengelolaan program WISMP di GP3A Mitra Tani. Penilaian kinerja GP3A Mitra Tani dianalisis dengan menggunakan metode Importance Performance Analysis. Data yang dikumpulkan kemudian diolah dan dianalisis sehingga mampu memberikan gambaran dan penjelasan terhadap permasalahan dalam penelitian ini.

\section{HASIL DAN PEMBAHASAN}

Dari dampak dari pelaksanaan WISMP I terhadap GP3A yang dilaksanakan di Kabupaten Bogor maka dapat dilihat perbedaan antara GP3A dengan Program WISMP dan GP3A Tanpa Program WISMP (Tabel 1).

Tabel 1. Perbedaan GP3A Dengan Program WISMP dan GP3A Tanpa Program WISMP

\begin{tabular}{|c|c|c|}
\hline Komponen & $\begin{array}{c}\text { GP3A Mitra Tani } \\
\text { Dengan Program WISMP }\end{array}$ & $\begin{array}{c}\text { GP3Aleubak } \\
\text { Tanpa Program WISMP }\end{array}$ \\
\hline $\begin{array}{l}\text { Aspek } \\
\text { Organisasi/Kelem } \\
\text { bagaan }\end{array}$ & $\begin{array}{ll}\text { - } & \text { Memiliki AD/ART, } \\
\text { - } & \text { Memiliki rekening bank, } \\
\text { - } & \text { Sudah berbadan hukum, } \\
\text { - } & \text { Tertib Adminitrasi, dan mampu } \\
& \text { mengatasi masalah organisasi }\end{array}$ & $\begin{array}{l}\text { - Belum ada aturan yang mengatur } \\
\text { kelompok, } \\
\text { - Belum adanya rekam data administrasi, } \\
\text { - Belum mampu mengatasi } \\
\text { permasalahan yang muncul dalam } \\
\text { kelompoknya }\end{array}$ \\
\hline $\begin{array}{l}\text { Aspe } \\
\text { Iriga }\end{array}$ & 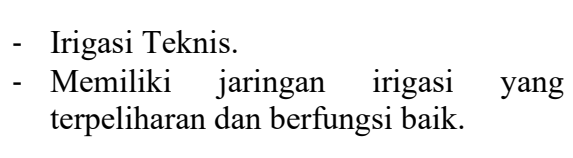 & $\begin{array}{l}\text { - Irigasi Sederhana, } \\
\text { - Masih sering terjadi konflik pembagian } \\
\text { air diantara anggota atau dengan pihak } \\
\text { luar. }\end{array}$ \\
\hline $\begin{array}{l}\text { Aspek Teknis } \\
\text { Usaha Tani }\end{array}$ & $\begin{array}{l}\text { - Sudah dapat meningkatkan } \\
\text { produktivitas hasil tanaman dari waktu } \\
\text { ke waktu dan mempertahankannya } \\
\text { pada tingkat yang tinggi melalui } \\
\text { pengaturan air yang baik dan efisien. } \\
\text { - Pola: Padi - Padi - Ubi jalar } \\
\text { - Produksi Padi Cenderung meningkat di } \\
\text { atas } 5 \text { ton/ha } \\
\text { - Pendapatan pengurus dan anggota } \\
\text { GP3A meningkat dengan adanya } \\
\text { peningkatan daya beli, tingkat } \\
\text { kesehatan, dan pendidikan rata-rata }\end{array}$ & $\begin{array}{l}\text { - Belum mampu meningkatkan dan } \\
\text { mempertahankan intensitas tanaman } \\
\text { pada tingkat yang tinggi karena masih } \\
\text { belum optimalnya pola pengaturan air } \\
\text { yang efisien (disamping aspek } \\
\text { pertanian lain non-irigasi). } \\
\text { - Belum menerapkan pola tanam sendiri. } \\
\text { - Belum mampu meningkatkan produksi } \\
\text { padi, masih di bawah } 3 \text { ton/ha } \\
\text { - Pendapatan belum meningkat (statis) }\end{array}$ \\
\hline
\end{tabular}
anak sekolah 


\begin{tabular}{|c|c|c|}
\hline Komponen & $\begin{array}{c}\text { GP3A Mitra Tani } \\
\text { Dengan Program WISMP }\end{array}$ & $\begin{array}{c}\text { GP3Aleubak } \\
\text { Tanpa Program WISMP }\end{array}$ \\
\hline $\begin{array}{l}\text { Aspek Keuangan } \\
\text { dan Bidang } \\
\text { Usaha }\end{array}$ & $\begin{array}{l}\text { - } \text { Tersedia dari Iuran Anggota. } \\
\text { - Terwujudnya perkumpulan petani } \\
\text { pemakai air yang dapat menghimpun } \\
\text { dana } 50 \% \text { dari Angka Kebutuhan Nyata } \\
\text { Operasi \& Pemeliharaan jaringan } \\
\text { primer dan sekunder. }\end{array}$ & $\begin{array}{l}\text { - belum memiliki usaha ekonomi lain } \\
\text { yang mandiri yang mendapat bantuan } \\
\text { permodalan dari lembaga pembiayaan }\end{array}$ \\
\hline $\begin{array}{l}\text { Aspek Peran } \\
\text { Pemerintah }\end{array}$ & $\begin{array}{l}\text { Mendapatkan pelatihan, penyuluhan, } \\
\text { pendampingan dan sebagainya yang } \\
\text { sesuai kebutuhan P3A, GP3A, dan } \\
\text { IP3A. }\end{array}$ & $\begin{array}{l}\text { - Kurangnya pendampingan petani dan } \\
\text { unit pemberdayaan dengan sumber } \\
\text { daya manusia yang handal ditingkat } \\
\text { kabupaten/kota. }\end{array}$ \\
\hline
\end{tabular}

Sumber : Data primer diolah

\section{Kinerja Proyek}

Menurut Rivai dan Basri (2005) pengertian kinerja adalah kesediaan seseorang atau kelompok orang untuk melakukan sesuatu kegiatan dan menyempurnakannya sesuai dengan tanggung jawab dengan hasil seperti yang diharapkan. Sedangkan menurut Bambang Guritno dan Waridin (2005) kinerja merupakan perbandingan hasil kerja yang dicapai oleh karyawan dengan standar yang telah ditentukan.

Dalam penilaian kinerja proyek yang dijalankan oleh GP3A dengan Program WISMP dan GP3A tanpa Program WISMP dilihat dari aspek Usahatani mengenai pola tanam, tingkat produksi dan pendapatan petani. Aspek Usahatani tersebut dapat dijabarkan sebagai berikut.

\section{Pola Tanam}

Dari data sekunder Surat Keputusan Buapti Bogor Nomor 611/668/Kpts/PerUU/2012 tanggal 18 Desember 2012 tentang Penetapan Pola Tanam dan Tata Tanam (Musim Hujan dan Musim Kemarau) Tahun 2012-2013 Pada Daerah Irigasi Pemerintah dan Irigasi Desa di Kabupaten Bogor, diketahui untuk GP3A Mitra Tani pada Daerah Irigasi Cianten Cigatet Kecamatan Leuwiliang, diterapkan Pola I yaitu Padi - Padi - Palawija (Ubi Jalar) untuk satu tahun musim tanam yang di mulai pada musim penghujan untuk MT I antara bulan Oktober 2012 sampai dengan bulan Pebruari 2013 dengan tanam padi, MT II antara bulan Pebruari sampai dengan bulan Juni 2013 dengan tanam padi dan terakhir MT III antara bulan Juli sampai dengan September 2013 dengan menanam palawija.

Untuk GP3A Leubak pada kurun waktu tersebut belum mampu melakukan pola tanam seperti yang dilakukan oleh GP3A Mitra Tani, karena kondisi daerah irigasi yang belum terpelihara dengan baik dan adanya bocoranbocoran yang belum tertangani secara optimal, seperti halnya pemanfaatan air irigasi selain untuk pertanian, melainkan untuk komersil, seperti contoh yaitu oleh kolam pemancingan, tempat pencucian kendaraan bermotor, rumah tangga bahkan oleh salah satu badan usaha milik daerah, yang mana air tersebut tidak kembali secara utuh kedalam jaringan irigasi semula, sehingga debit air yang dibutuhkan oleh petani di GP3A Leubak daerah irigasi citeureup sangat jauh berkurang yang menyebabkan krisis air untuk persawahan yang akhirnya tidak dapat menerapkan pola tanam sesuai yang diharapkan.

\section{Tingkat Produksi GP3A}

Penggunaan input dalam kegiatan usaha tani responden antara GP3A Mitra Tani dan GP3A Leubak di Kecamtan Leuwiliang dan Kabupaten Bogor menunjukan bahwa secara umum penggunaan inputnya tidak terlalu berbeda hanya saja tingkat penggunaan input di GP3A Leubak lebih besar dibandingkan dengan GP3A Mitra Tani.

Penggunaan input pada GP3A Mitra Tani lebih sedikit dibandingkan pada GP3A Leubak namun hasil produksinya lebih banyak yakni berselisih $1.873,01 \mathrm{~kg}$. Hal ini bisa jadi sebagai efek dari keberadaan program WISMP yang telah memberikan pembinaan dan pelatihan terhadap anggotannya. Penggunaan pupuk pada GP3A Mitra Tani dapat dikatakan lebih efektif dibandingkan dengan GP3A Leubak. Penggunaan tenaga kerja di GP3A Mitra Tani lebih rendah dibandingkan dengan GP3A Leubak yakni berselisih 22,17 HOK. Hal ini disebabkan proporsi penggunaan tenaga kerja oleh GP3A Leubak untuk penanaman dan pemanenan cenderung dilakukan dengan sistem borongan. Perbandingan rata-rata penggunaan input (Tabel 2).

Strategi Peningkatan Kinerja Gabungan Perkumpulan Petani Pemakai Air (GP3A) Di Kabupatan Bogor 
Tabel 2. Perbandingan Rata-Rata Penggunaan Input dan Hasil Antara Petani GP3A Penerima Program WISMP Dan GP3A Bukan Penerima Program WISMP

\begin{tabular}{llll}
\hline Uraian & GP3A Mitra Tani & GP3A Leubak & Selisih \\
\hline Produksi & & & \\
- Luas lahan $(\mathrm{Ha})$ & 421 & 125 & 296 \\
- Hasil $(\mathrm{Kg} / \mathrm{Ha})$ & $5.631,98$ & $3.758,97$ & $1.873,01$ \\
& & & \\
Input & 22,31 & 40,10 & $-17,78$ \\
- Benih $(\mathrm{Kg} / \mathrm{Ha})$ & & & \\
- Pupuk $(\mathrm{Kg} / \mathrm{Ha})$ & 208,97 & 295,13 & $-86,16$ \\
$\quad$ a. Urea & 95,29 & 149,36 & $-54,07$ \\
$\quad$ b. SP36 & 74,87 & 35,88 & 38,99 \\
$\quad$ c. KCL & 95,18 & 117,35 & $-22,17$ \\
- Tenaga Kerja (HOK) & &
\end{tabular}

Sumber : Data Primer diolah

\section{Perbedaan Kinerja GP3A WISMP dan GP3A Non WISMP}

Berdasarkan PP 20/2006 (pasal 26) bentuk-bentuk partisipasi masyarakat petani dimulai dari proses perencanaan, pengambilan keputusan, kontribusi, sumberdaya manusia dan kemampuan teknis dalam pengelolaan jaringan irigasi. Hal ini dimaksudkan agar bisa ditindak lanjuti pada posisi mana tingkat partisipasi GP3A tersebut yang perlu ditingkatkan atau perlu dipertahankan.

Tabel 3. Perbedaan Kinerja GP3A Dengan Program WISMP dan GP3A Tanpa Program WISMP

\begin{tabular}{|c|c|c|c|}
\hline No & Komponen & $\begin{array}{c}\text { GP3A Dengan } \\
\text { Program WISMP }\end{array}$ & $\begin{array}{c}\text { GP3A Tanpa } \\
\text { Program WISMP }\end{array}$ \\
\hline 1 & Irigasi & Irigasi Teknis & Irigasi Sederhana \\
\hline 2 & Pengaturan Pola Tanam & 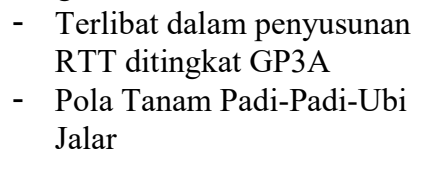 & 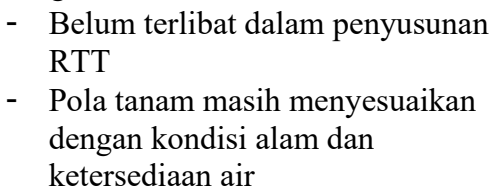 \\
\hline 3 & Hasil produksi & $\begin{array}{l}\text { Rata-rata mencapai di atas } \pm 5 \\
\text { ton/Ha }\end{array}$ & $\begin{array}{l}\text { Rata-rata baru mencapai di atas } \pm 3 \\
\text { ton/Ha }\end{array}$ \\
\hline
\end{tabular}

Dari Tabel di atas menunjukan perbedaan yang sangat signifikan dalam kontribusi pengelolaan jaringan irigasi, dapat dilihat bahwa GP3A yang mendapatkan program WISMP, lebih terarah dan teratur dalam kontribusi pengelolaan jaringan irigasi, sehingga memperlihatkan kinerja yang lebih baik dari pada GP3A yang tidak menerima program WISMP. Dengan demikian bisa menjadi tolok ukur bagi Pemerintah Daerah Kabupaten Bogor khususnya Dinas Bina Marga dan Pengairan dalam melakukan pembinaan terhadap GP3A.

\section{Tingkat Kepentingan dan Kepuasan Kualitas Kinerja}

Hasil evaluasi kinerja GP3A dengan menggunakan metode ImportancePerformance Analysis (IPA) seperti yang terlihat pada Tabel 3 adalah data antara tingkat kepentingan dan kepuasan terhadap kualitas kinerja responden yang akan digunakan untuk membuat diagram kartesius mengenai posisi penempatan data berdasarkan ImportancePerformance Analysis (IPA). 
Tabel 4. Perbandingan Tingkat Kepentingan dan Tingkat Kepuasan Kualitas Kinerja Responden

\begin{tabular}{|c|c|c|c|c|}
\hline \multirow{2}{*}{ Variabel } & \multirow{2}{*}{ Indikator } & \multirow{2}{*}{$\begin{array}{c}\text { Tingkat } \\
\text { Kepentingan }\end{array}$} & \multirow{2}{*}{$\begin{array}{l}\text { WISMP } \\
\text { Kualitas } \\
\text { Kinerja }\end{array}$} & \multirow{2}{*}{$\begin{array}{c}\text { Non } \\
\text { WISMP } \\
\text { Kualitas } \\
\text { Kinerja } \\
\end{array}$} \\
\hline & & & & \\
\hline \multirow{6}{*}{$\begin{array}{l}\text { A. Aspek Organisasi / } \\
\text { Kelembagaan }\end{array}$} & 1 GP3A memiliki AD/ART & 4,67 & 3,6 & 1,67 \\
\hline & 2 GP3A Berbadan Hukum & 4,27 & 3,87 & 1,67 \\
\hline & 3 Memilki Bank Rekening dan NPWP. & 3,7 & 3,2 & 1 \\
\hline & $\begin{array}{l}4 \text { Tertib admnistrasinya (ada peta jaringan irigasi, } \\
\text { buku anggota, program kerja dan sebagainya). }\end{array}$ & 4,23 & 3,67 & 1,8 \\
\hline & 5 GP3A aktif melakukan pertemuan/rapat pengurus & 3,97 & 2,93 & 2,07 \\
\hline & $\begin{array}{l}6 \text { Dapat mengatasi masalah organisasi, mengatasi } \\
\text { konflik antar anggota atau dengan pihak luar. }\end{array}$ & 4,1 & 1,93 & 2,07 \\
\hline \multirow{5}{*}{ B. Aspek Teknis Irigasi } & $\begin{array}{l}1 \text { Memiliki jaringan irigasi yang terpeliharan dan } \\
\text { berfungsi baik. }\end{array}$ & 4,27 & 3,13 & 1,93 \\
\hline & $\begin{array}{l}2 \text { Mampu membuat Rencana Tata Tanam Detail dan } \\
\text { Rencana Pembagian Airnya setiap tahun. }\end{array}$ & 3,7 & 2,93 & 1 \\
\hline & $\begin{array}{l}3 \text { Dapat memberi rasa keadilan kepada anggota } \\
\text { (hulu dan hilir) dalam pembagian air. }\end{array}$ & 4,6 & 2,8 & 1,33 \\
\hline & $\begin{array}{l}4 \text { Dapat memecahkan masalah, menekan/meredakan } \\
\text { konflik pembagian air diantara anggota atau } \\
\text { dengan pihak luar. }\end{array}$ & 4,5 & 2,67 & 1,47 \\
\hline & $\begin{array}{l}5 \text { GP3A dapat berpartisipasi pada kegiatan } \\
\text { pengembangan dan pengelolaan sistem jaringan. }\end{array}$ & 4,37 & 2,67 & 1 \\
\hline \multirow{3}{*}{$\begin{array}{l}\text { C. Aspek Teknis Usaha } \\
\text { Tani }\end{array}$} & $\begin{array}{l}1 \text { Dapat meningkatkan dan mempertahankan } \\
\text { intensitas tanaman pada tingkat yang tinggi } \\
\text { dengan pengaturan air yang efisien (disamping } \\
\text { aspek pertanian lain non-irigasi). }\end{array}$ & 4,53 & 3 & 2,07 \\
\hline & $\begin{array}{l}2 \text { Dapat memperkecil perbedaan produktivitas hasil } \\
\text { tanaman daerah hulu dan hilir melalui pengaturan } \\
\text { air yang adil. }\end{array}$ & 4,67 & 3,87 & 1,87 \\
\hline & $\begin{array}{l}3 \text { Dapat meningkatkan produktivitas hasil tanaman } \\
\text { dari waktu ke waktu dan mempertahankannya } \\
\text { pada tingkat yang tinggi melalui pengaturan air } \\
\text { yang baik dan efisien. }\end{array}$ & 4,83 & 4 & 1,87 \\
\hline \multirow{3}{*}{$\begin{array}{l}\text { D. Aspek Keuangan dan } \\
\text { Bidang Usaha }\end{array}$} & $\begin{array}{l}1 \text { Terwujudnya perkumpulan petani pemakai air } \\
\text { yang dapat menghimpun dana } 50 \% \text { dari Angka } \\
\text { Kebutuhan Nyata Operasi \& Pemeliharaan } \\
\text { jaringan primer dan sekunder. }\end{array}$ & 4,6 & 3,8 & 1 \\
\hline & $\begin{array}{l}2 \text { Dapat menggerakan di atas } 70 \% \text { jumlah } \\
\text { anggotanya untuk memberi kontribusi iuran } \\
\text { pengelolaan irigasi. }\end{array}$ & 4,7 & 3,73 & 1 \\
\hline & $\begin{array}{l}3 \text { GP3A memiliki usaha ekonomi lain yang mandiri } \\
\text { dan mendapat bantuan permodalan dari lembaga } \\
\text { pembiayaan }\end{array}$ & 4,47 & 3 & 1 \\
\hline \multirow{3}{*}{$\begin{array}{l}\text { E. Aspek Peran } \\
\text { Pemerintah }\end{array}$} & $\begin{array}{l}1 \text { Adanya program pemberdayaan dalam bentuk } \\
\text { pelatihan, penyuluhan, pendampingan dan } \\
\text { sebagainya yang sesuai kebutuhan P3A, GP3A, } \\
\text { dan IP3A. }\end{array}$ & 4,83 & 3,8 & 2,8 \\
\hline & $\begin{array}{l}2 \text { Adanya alokasi dana yang mencukupi untuk } \\
\text { menunjang program pemberdayaan tersebut. }\end{array}$ & 5 & 3 & 2,27 \\
\hline & \begin{tabular}{|l|}
3 Adanya pendampingan petani dan unit \\
pemberdayaan dengan sumber daya manusia yang \\
handal ditingkat kabupaten/kota.
\end{tabular} & 5 & 2,93 & 2,73 \\
\hline \multicolumn{2}{|r|}{ Jumlah } & 4,45 & 3,23 & 1,68 \\
\hline
\end{tabular}

Sumber : Data primer. Telah diolah.

Dari tabel di atas diketahui bahwa tingkat kepentingan terhadap indikator tingkat kualitas kinerja GP3A Mitra Tani dan GP3A

Bobby Wahyudi, Yusman Syaukat, dan Lala M Kolopaking
Leubak setelah dirata-ratakan. Menurut Martinez, 2003 ada dua macam metode untuk menampilkan data IPA, yaitu pertama 
menempatkan garis perpotongan kuadran pada nilai rata-rata sumbu tingkat kepuasan dan sumbu prioritas penanganan dengan tujuan untuk mengetahui secara umum penyebaran data terletak pada kuadran berapa, kedua menempatkan garis perpotongan kuadran pada nilai rata-rata hasil pengamatan pada sumbu tingkat kepuasan dan sumbu perioritas penanganan dengan tujuan untuk mengetahui secara sepesifik masing-masing faktor terletak pada kuadran berapa.

Untuk tingkat kepentingan terhadap indikator penilaian kualitas kinerja dari GP3A Mitra Tani sebagai penerima program WISMP dan GP3A Leubak sebagai bukan penerima program WISMP menunjukan skor 4,45 artinya bahwa kedua GP3A menganggap seluruh aspek tersebut adalah penting untuk dilakukan agar dapat mengembangkan penguatan pengelolaan irigasi partisipatif yang berkelajutan di Kabupaten Bogor. Untuk penilaian tingkat kepuasan responden terhadap aspek-aspek tersebut pada kondisi saat ini oleh GP3A Mitra Tani dengan skor 3,23 artinya GP3A Mitra Tani merasa cukup puas dengan kulitas kinerja yang telah mereka capai sampai saat ini, namun tentunya dengan meningkatkan variabel GP3A aktif melakukan pertemuan/rapat pengurus, dapat mengatasi masalah organisasi, mengatasi konflik antar anggota atau dengan pihak luar, dapat memecahkan masalah, menekan/meredakan konflik pembagian air diantara anggota atau dengan pihak luar, serta GP3A dapat berpartisipasi pada kegiatan pengembangan dan pengelolaan sistem jaringan, yang merupakan prioritas utama bagi
GP3A untuk menentukan alternatif strategi dengan demikian diharapkan kulitas kinerja GP3A menjadi lebih optimal.

Sedangkan penilaian tingkat kepuasan responden terhadap aspek-aspek di atas pada kondisi saat ini oleh GP3A Leubak dengan skor 1,68 dinilai sangat rendah, artinya GP3A Leubak masih belum puas dengan kualitas kinerja mereka sampai saat ini, sehingga diperlukan peningkatan dari baerbagai aspek agar kinerja GP3A Leubak kedepannya dapat lebih optimal.

Dari hasil skoring kuisioner responden terhadap tingkat kepentingan dan tingkat kualitas kinerja diketahui perbedaan antara GP3A Mitra Tani sebagai penerima program WISMP dan GP3A Leubak sebagai bukan penerima program WISMP dengan selisih skor kualitas kinerja sebesar 1,55 lebih besar GP3A Mitra Tani menunjukan bahwa ada manfaat perubahan dari seluruh aspek indikator kualitas kinerja dengan adanya program WISMP di Kabupaten Bogor.

IPA menyatukan pengukuran faktor tingkat kepentingan (importance) dan tingkat kepuasan (performance) yang kemudian digambarkan dalam diagram dua dimensi yaitu diagram importance-performance untuk mendapatkan usulan praktis dan memudahkan penjelasan data, dimana pusat pemotongan garis adalah nilai rata-rata yang terdapat pada dimensi kepentingan dan kepuasan. Grafik IPA dibagi menjadi empat buah kuadran berdasarkan hasil pengukuran Importance Performance Analysis seperti yang terlihat pada Gambar berikut.

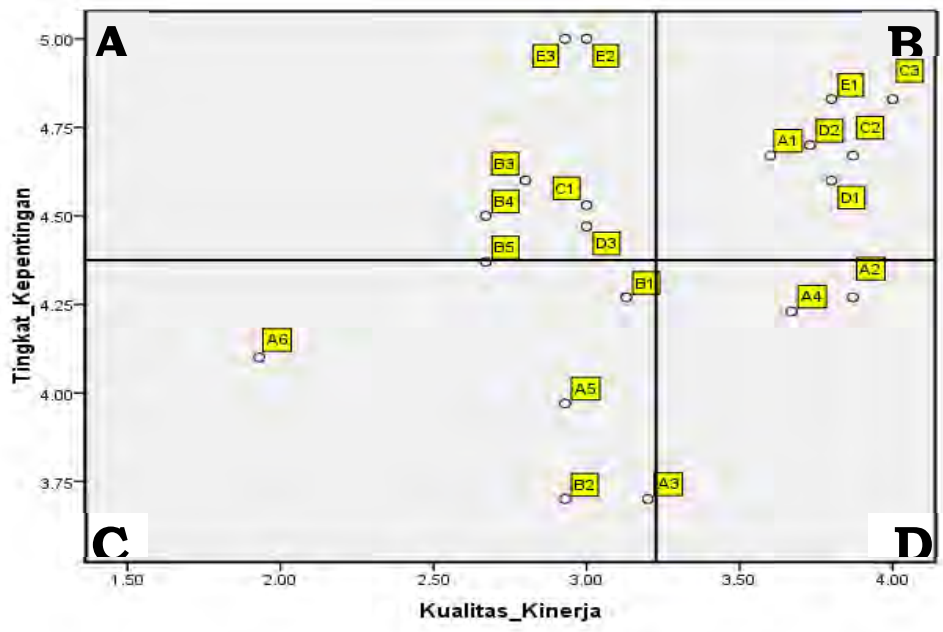

Sumber : Data primer telah diolah

Gambar 2. Pembagian Kuadran IPA Terhadap Hasil Pengukuran Tingkat Kinerja dan 
Berdasarkan grafik IPA pada gambar 5.2 di atas, maka indikator yang berkaitan dengan tingkat kinerja dan kualitas kinerja GP3A yang berada di Kabupaten Bogor dapat dikelompokan dalam masing-masing kuadran sebagai berikut :

1. Kuadran A : Tingkatkan Kinerja

Pada kuadran A terdapat enam variabel (30 $\%)$ yang dinilai sangat penting dan sesuai dengan keinginan anggotanya. Variabel yang terdapat dalam kuadran ini dianggap sebagai faktor yang sangat penting namun kondisinya saat ini belum memuaskan responden, sehingga lembaga atau instansi terkait dipandang perlu untuk meningkatkan kinerja pada berbagai sektor tersebut.

2. Kuadran B : Pertahankan Kinerja

Yang termasuk dalam Kuadran B terdapat enam variabel $(30 \%)$, yang di nilai sudah optimal dalam pelaksanaanya. Variabel kinerja yang terletak pada kuadran ini dianggap sebagai faktor penunjang bagi pengembangan kelembagaan GP3A penerima Program WISMP.

3. Kuadran $\mathrm{C}$ : Prioritas Rendah

Pada kuadran $\mathrm{C}$ terdapat enam variabel (30\%) yang dinilai tingkat kepentingan dan kinerjanya rendah. Variabel ini memiliki tingkat kepuasan yang rendah cenderung belum dianggap penting oleh petani responden.

4. Kuadran D : Cenderung Berlebihan Pada kuadran D terdapat dua variabel (10\%) yang dinilai tingkat kepentingan rendah dengan kinerjanya tinggi, dengan kata lain pada kuadran ini beberapa variabel dilaksanakan secara berlebihan. Variabel yang terletak pada kuadran ini dianggap sudah baik namun tidak dianggap penting oleh petani responden.

Dari hasil Importance-Performance Analysis (IPA), terhadap tingkat kepentingan dan tingkat kualitas kinerja diketahui perbedaan antara GP3A Mitra Tani sebagai penerima program WISMP dan GP3A Leubak sebagai bukan penerima program WISMP dengan selisih skor kualitas kinerja sebesar 1,55 lebih besar GP3A Mitra Tani menunjukan bahwa ada manfaat perubahan dari seluruh aspek indikator kualitas kinerja dengan adanya program WISMP di Kabupaten Bogor.

Bobby Wahyudi, Yusman Syaukat, dan Lala M Kolopaking

\section{Faktor Internal dan Eksternal Yang Berpengaruh Terhadap Peningkatan Kinerja GP3A di Kabupaten Bogor}

Untuk mengetahui faktor-faktor strategis yang berpengaruh terhadap peningkatan kinerja GP3A di Kabupaten Bogor digunakan analisis faktor internal eksternal. Tahap awal analisis ini adalah mengidentifikasi terlebih dahulu indikator faktor internal yaitu kekuatan dan kelemahan dan indikator eksternal yaitu peluang dan ancaman. Berdasarkan hasil wawancara diperoleh beberapa faktor stratetgis dalam rangka peningkatan kinerja GP3A di Kabupaten Bogor. Faktor strategis tersebut terdiri dari faktor internal yang meliputi kekuatan dan kelemahan, serta faktor eksternal yang meliputi peluang dan ancaman.

\section{Faktor Strategis Internal}

Beberapa faktor internal yang berpengaruh terhadap peningkatan kinerja GP3A di Kabupaten Bogor, untuk faktor kekuatan (strengths) antara lain : (1) Lahan sawah masih cukup luas dan sumber air tersedia cukup; (2) Petani sudah mempunyai wadah untuk berpartisipasi melaui GP3A; (3) Komisi Irigasi Kabupaten Bogor sudah terbentuk dan Perda Irigasi sudah terbit; (4) Jaringan irigasi berfungsi dengan baik; (5) Pemerintah Daerah Kabupaten Bogor menyediakan Dana Pendamping untuk penerapan pengelolaan irigasi partisipatif. Yang menjadi faktor kelemahan (weaknesses) meliputi : (1) Kurangnya pengalaman dan pelatihan; (2) Rendahnya kesadaran masyarakat dalam pengelolaan air; (3) Bukan pemilik lahan hanya penggarap; (4) Partisipasi petani hanya untuk mendapat upah; (5) Kurangnya dukungan dana untuk pembinaan petani.

\section{Faktor Strategis Eksternal}

Beberapa faktor internal yang berpengaruh terhadap pengembangan penguatan program WISMP terhadap pengelolaan irigasi partisipatif yang berkelanjutan di Kabupaten Bogor, untuk faktor peluang (opportunities) antara lain : (1) Mekanisme partisipatif sudah disebut jelas dalam UU SDA No 7/2004, PP Irigasi no 20/2006, Permen PU No 30/2007 tentang Pedoman Pengelolaan Irigasi Partisipatif; (2) Tersedianya dana hibah dari Pemerintah Pusat untuk penerapan pengelolaan irigasi partisipatif; (3) Adanya pendamping masyarakat untuk petani; (4) Adanya usaha

Strategi Peningkatan Kinerja Gabungan Perkumpulan Petani Pemakai Air (GP3A) Di Kabupatan Bogor 
untuk menjaga jaringan irigasi dapat berfungsi dengan baik; (5) Adanya usaha untuk meningkatkan produksi padi untuk meningkatkan pendapatan petani. Sedangkan yang menjadi faktor ancaman (threats) meliputi : (1) Rendahnya tingkat koordinasi antar stakeholder terkait; (2) Kurangnya jumlah Tenaga Pendamping Masyarakat; (3) Alih fungsi lahan (4) Kurangnya Sosialisasi; (5) GP3A berperan sebagai kontraktor.

\section{Matrik IFE - EFE}

Untuk melakukan analisis terhadap faktor-faktor strategis yang mempengaruhi peningkatan kinerja GP3A di Kabupaten Bogor digunakan matrik Internal Factor Evaluation (IFE) dan untuk faktor Internal dan matrik
External Factor Evaluation (EFE) untuk faktor eksternal. Tujuan menggunakan matrik IFE dan matrik EFE ini untuk mengetahui seberapa besar pengaruh faktor-faktor strategis internal dan ekternal terhadap keberhasilan peningkatan kinerja GP3A di Kabupaten Bogor.

\section{Hasil Evaluasi Faktor Internal}

Faktor-faktor strategis internal yang mempengaruhi peningkatan kinerja GP3A di Kabupaten Bogor setelah diperoleh dari pengumpulan data kuisioner sepuluh orang responden untuk penelitian bobot dan rating maka diperoleh hasil perhitungannya pada Table 5.

Tabel 5. Hasil Matrik IFE (Internal Factor Evaluation)

\begin{tabular}{clccc}
\hline No & \multicolumn{1}{c}{ Faktor-faktor Strategis Internal } & Bobot & Rating & Skor \\
\hline & Kekuatan : & & & \\
1 & Lahan sawah masih cukup luas dan sumber air tersedia cukup; & 0,11 & 4 & 0,42 \\
2 & Petani sudah mempunyai wadah untuk berpartisipasi melaui & 0,10 & 4 & 0,41 \\
& GP3A; & & & \\
3 & $\begin{array}{l}\text { Komisi Irigasi Kabupaten Bogor sudah terbentuk dan Perda } \\
\text { Irigasi sudah terbit; }\end{array}$ & 0,10 & 4 & 0,39 \\
4 & Jaringan irigasi berfungsi dengan baik; & 0,10 & 4 & 0,40 \\
5 & Pemerintah Daerah Kabupaten Bogor menyediakan Dana & 0,08 & 3 & 0,25 \\
& Pendamping untuk penerapan pengelolaan irigasi partisipatif & $\mathbf{0 , 4 9}$ & & $\mathbf{1 , 8 7}$ \\
\hline$\quad$ Jumlah & & & \\
& Kelemahan : & 0,10 & 4 & 0,39 \\
6 & Kurangnya pengalaman dan pelatihan & 0,10 & 4 & 0,41 \\
7 & Rendahnya kesadaran masyarakat dalam pengelolaan air & 0,10 & 4 & 0,40 \\
8 & Bukan pemilik lahan hanya penggarap & 0,11 & 4 & 0,43 \\
9 & Partisipasi petani hanya untuk mendapat upah & 0,10 & 4 & 0,41 \\
10 & Kurangnya dukungan dana untuk pembinaan petani & $\mathbf{0 , 5 1}$ & & $\mathbf{2 , 0 5}$ \\
\hline & Jumlah & $\mathbf{1 , 0 0}$ & & $\mathbf{3 , 9 2}$ \\
\hline
\end{tabular}

Sumber : Data primer diolah

Peningkatan kinerja GP3A di Kabupaten Bogor ditentukan oleh faktor internal dengan tingkat kepentingan relatif satu faktor dengan faktor lainnya ditentukan oleh besarnya bobot faktor tersebut. Pada Tabel 5. 13 dapat dilihat bahwa faktor internal yang dinilai paling penting terhadap keberhasilan peningkatan kinerja GP3A di Kabupaten Bogor adalah lahan sawah masih cukup luas dan sumber air tersedia cukup, dengan nilai sebesar 0,42 dengan peringkat sebesar 4 yang berarti faktor tersebut merupakan salah satu faktor kekuatan utama.

Selain mengidentifikasi kekuatan internal, matrik IFE juga menunjukan berbagai kelemahan dalam peningkatan kinerja GP3A di Kabupaten Bogor. Faktor internal yang dimiliki Bobby Wahyudi, Yusman Syaukat, dan Lala M Kolopaking kelemahan terbesar adalah partisipasi petani hanya untuk mendapat upah yang memiliki nilai sebesar 0,43. Hal ini menunjukan bahwa dalam peningkatan kinerja GP3A di Kabupaten Bogor harus mampu merubah pola pikir mereka sehingga orientasinya berubah menjadi lebih baik dari sekedar mendapatkan upah saja.

\section{Hasil Evaluasi Faktor Eksternal}

Berdasarkan hasil identifiksi faktor strategis eksternal yang mempengaruhi peningkatan kinerja GP3A di Kabupaten Bogor yang terdiri dari peluang dan ancaman, kemudian dilanjutkan dengan evaluasi faktor eksternal menggunakan matrik EFE diperoleh

Strategi Peningkatan Kinerja Gabungan Perkumpulan Petani Pemakai Air (GP3A) Di Kabupatan Bogor 
hasil seperti pada Tabel Hasil Matrik EFE. Bobot yang diperoleh menentukan tingkat kepentingan relatif satu faktor eksternal terhadap faktor eksternal lainnya yang berpengaruh pada peningkatan kinerja GP3A di Kabupaten Bogor.

Tabel 6. Hasil Matrik EFE (External Factor Evaluation)

\begin{tabular}{|c|c|c|c|c|}
\hline No & Faktor-Faktor Strategis Eksternal & Bobot & Rating & Skor \\
\hline \multirow{3}{*}{1} & Peluang : & & & \\
\hline & $\begin{array}{l}\text { Mekanisme partisipatif sudah disebut jelas dalam UU SDA No } \\
7 / 2004 \text {, PP Irigasi no } 20 / 2006 \text {, Permen PU No } 30 / 2007 \text { tentang }\end{array}$ & 0,10 & 3 & 0,31 \\
\hline & Pedoman Pengelolaan Irigasi Partisipatif; & & & \\
\hline 2 & $\begin{array}{l}\text { Tersedianya dana hibah dari Pemerintah Pusat untuk penerapan } \\
\text { pengelolaan irigasi partisipatif; }\end{array}$ & 0,10 & 3 & 0,31 \\
\hline 3 & Adanya pendamping masyarakat untuk petani; & 0,10 & 3 & 0,31 \\
\hline 4 & $\begin{array}{l}\text { Adanya usaha untuk menjaga jaringan irigasi dapat berfungsi } \\
\text { dengan baik; }\end{array}$ & 0,11 & 3 & 0,32 \\
\hline \multirow[t]{3}{*}{5} & $\begin{array}{l}\text { Adanya usaha untuk meningkatkan produksi padi untuk } \\
\text { meningkatkan pendapatan petani. }\end{array}$ & 0,10 & 3 & 0,30 \\
\hline & Jumlah & $\mathbf{0 , 5 2}$ & & $\mathbf{1 , 5 5}$ \\
\hline & Ancaman : & & & \\
\hline 6 & Rendahnya tingkat koordinasi antar stakeholder terkait & 0,09 & 3 & 0,28 \\
\hline 7 & Kurangnya jumlah Tenaga Pendamping Masyarakat & 0,08 & 2 & 0,15 \\
\hline 8 & Alih fungsi lahan & 0,09 & 3 & 0,28 \\
\hline 9 & Kurangnya Sosialisasi & 0,12 & 4 & 0,47 \\
\hline \multirow[t]{3}{*}{10} & GP3A berperan sebagai kontraktor & 0,10 & 3 & 0,30 \\
\hline & Jumlah & $\mathbf{0 , 4 8}$ & & 1,49 \\
\hline & Jumlah Total & 1,00 & & $\mathbf{3 , 0 4}$ \\
\hline
\end{tabular}

Sumber : Data primer diolah

Berdasarkan Tabel matrik EFE terlihat bahwa faktor-faktor kunci eksternal yang memberikan peluang terbesar dalam peningkatan kinerja GP3A di Kabupaten Bogor adalah adanya usaha untuk menjaga jaringan irigasi dapat berfungsi dengan baik, peluang ini diharapkan dapat mendorong kemajuan peningkatan kinerja kelembagaan petani. Nilai skor terbesar yang dimiliki faktor kunci eksternal ini yaitu sebersar 0,32 dengan bobot 0,11 dan rating sebesar 3 .

Faktor eksternal yang memberikan ancaman terbesar bagi peningkatan kinerja GP3A di Kabupaten Bogor adalah kurangnya sosialisasi yang di tunjukan dengan bobot 0,12 dan rating 4 sehingga skornya menjadi 0,47 . Hal ini menunjukan bahwa dalam peningkatan kinerja GP3A di Kabupaten Bogor harus mampu mengatasi ancaman terbesar yaitu meningkatkan sosialisasi sehingga jika masyarakat petani yang di wakili oleh lembaga GP3A maka akan meningkatkan kualitas kinerja mereka.

\section{Perumusan Program}

Formulasi alternatif pengembangan program pengelolaan irigasi partisipatif yang berkelanjutan di Kabupaten Bogor diperoleh dengan tiga tahap yaitu (1) identifikasi faktor internal dan eksternal yang diperoleh melalui wawancara; (2) tahap penggabungan; dan terakhir (3) tahap pengambilan keputusan. Metoda yang digunakan dalam merumuskan strategi adalah pendekatan analisis SWOT, yakni dengan mencocokan faktor-faktor internal berupa kekuatan dan kelemahan dengan faktor-faktor ekternal berupa peluang dan ancaman, untuk mendapatkan alternatif strategi S-O, strategi W-O, strategi S-T dan strategi WT, dan QSPM (Quantitatif Strategic Planning Matrix).

Dari hasil evaluasi di atas maka di susun kedalam matrik SWOT untuk menganalisis antara kekuatan dengan kelemahan dan peluang dengan ancaman. Matriks SWOT tersebut digambarkan pada Tabel Matrik SWOT 
Tabel 7. Matriks SWOT strategi peningkatan kinerja GP3A di Kabupaten Bogor.

\begin{tabular}{|c|c|c|}
\hline Faktor Internal & $\begin{array}{ll}\frac{\text { Kekuatan }(\mathbf{S})}{1 .} & \text { Lahan sawah masih cukup luas dan } \\
\text { sumber air tersedia cukup; } \\
\text { 2. Petani sudah mempunyai wadah untuk } \\
\text { berpartisipasi melaui GP3A; } \\
\text { 3. Komisi Irigasi Kabupaten Bogor sudah } \\
\text { terbentuk dan Perda Irigasi sudah terbit; } \\
\text { 4. Jaringan irigasi berfungsi dengan baik; } \\
\text { 5. Pemerintah Daerah Kabupaten Bogor } \\
\text { menyediakan Dana Pendamping untuk } \\
\text { penerapan pengelolaan irigasi } \\
\text { partisipatif }\end{array}$ & \begin{tabular}{ll}
\multicolumn{2}{|}{ Kelemahan $(\mathbf{W})$} \\
1. \\
2. Rurangnya pengalaman dan pelatihan \\
pendahnya kesadaran masyarakat dalam \\
3. Bukan pemilik lahan hanya penggarap \\
4. Partisipasi petani hanya untuk mendapat \\
upah \\
5. Kurangnya dukungan dana untuk \\
pembinaan petani
\end{tabular} \\
\hline $\begin{array}{ll}\text { Peluang (O) } \\
\text { 1. } \\
\text { Mekanisme partisipatif sudah } \\
\text { disebut jelas dalam UU SDA No } \\
7 / 2004, \text { PP Irigasi no 20/2006, } \\
\text { Permen PU No 30/2007 tentang } \\
\text { Pedoman Pengelolaan Irigasi } \\
\text { Partisipatif; } \\
\text { 2. Tersedianya dana hibah dari } \\
\text { Pemerintah Pusat untuk } \\
\text { penerapan pengelolaan irigasi } \\
\text { partisipatif; } \\
\text { 3. Adanya pendamping masyarakat } \\
\text { untuk petani; } \\
\text { 4. Adanya usaha untuk menjaga } \\
\text { jaringan irigasi dapat berfungsi } \\
\text { dengan baik; } \\
\text { 5danya usaha untuk } \\
\text { meningkatkan produksi padi } \\
\text { untuk meningkatkan pendapatan } \\
\text { petani. }\end{array}$ & $\begin{array}{ll}\text { Strategi }(\mathrm{S}-\mathrm{O}) \\
1 . & \begin{array}{l}\text { Mengelola jaringan irigasi secara } \\
\text { partisipatif dengan dana yang ada } \\
(\mathrm{S} 1, \mathrm{~S} 2, \mathrm{~S} 3, \mathrm{~S} 4, \mathrm{O} 1, \mathrm{O} 3, \mathrm{O} 4) ;\end{array} \\
2 . & \begin{array}{l}\text { Memprogramkan rencana pengelolaan } \\
\text { jaringan irigasi secara partisipatif untuk }\end{array} \\
\text { peningkatan produksi dan peningkatan } \\
\text { kesejahteraan petani dalam RPJMD } \\
\text { Kabupaten Bogor } \\
(\mathrm{S} 3, \mathrm{~S} 4, \mathrm{~S} 5, \mathrm{O} 1, \mathrm{O} 2, \mathrm{O} 4, \mathrm{O} 5) ;\end{array}$ & 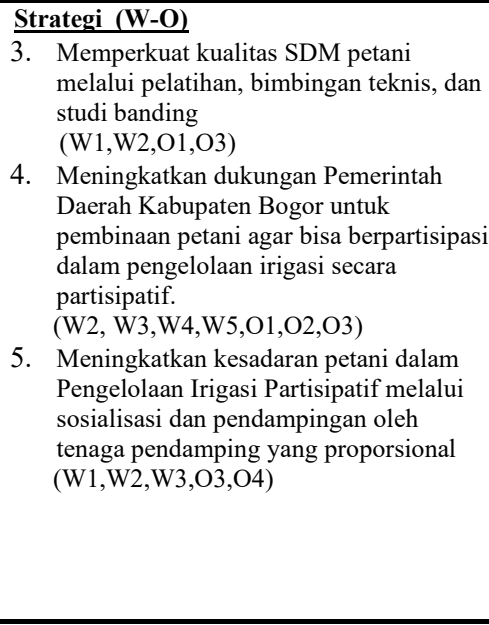 \\
\hline $\begin{array}{ll}\text { Ancaman (T) } \\
\text { 1. } & \text { Rendahnya tingkat koordinasi } \\
\text { antar stakeholder terkait } \\
\text { 2. } \\
\text { Kurangnya jumlah Tenaga } \\
\text { Pendamping Masyarakat } \\
\text { 3. Alih fungsi lahan } \\
\text { 4. Kurangnya Sosialisasi } \\
\text { 5. GP3A berperan sebagai } \\
\text { kontraktor }\end{array}$ & $\begin{array}{ll}\text { Strategi (S-T) } \\
6 . & \text { Memperkuat koordinasi antar } \\
\text { stakeholder melalui fungsi koordinasi } \\
\text { Komisi Irigasi; } \\
(\mathrm{S} 3, \mathrm{~S} 5, \mathrm{~T} 1, \mathrm{~T} 2)\end{array}$ & Strategi $(\mathrm{W}-\mathrm{T})$ \\
\hline
\end{tabular}

Berdasarkan hasil analisis SWOT, diperoleh 6 (enam) alternatif strategi yang dapat digunakan dalam Strategi Peningkatan Kinerja Gabungan Perkumpulan Petani Pemakai Air (GP3A) di Kabupaten Bogor. Dengan banyaknya alternatif strategi yang diperoleh, harus dipilih beberapa strategi yang akang di jadikan prioritas. Tahap pengambilan keputusan merupakan tahap selanjutnya dari perumusan strategi dengan menggunakan analisis Quantitative Strategic Planning Matrix (QSPM). Analisis ini ditunjukan untuk menentukan prioritas strategi pengembangan pengelolaan irigasi partisipatif di Kabupaten Bogor. Setelah dialakukan perhitungan nilai TAS, maka diperoleh hasil QSPM seperti disajikan pada Tabel 8 .

Analisis QSPM dilakukan dengan cara memberikan nilai kemenarikan relatif (Attractive Score $=$ AS) pada masing-masing faktor internal maupun ekternal. Strategi yang mempunyai total kemenarikan relatif (Total
Attractive Score $=$ TAS) tinggi merupakan prioritas utama strategi.

Berdasarkan hasil analisis QSPM Tabel 8 didapatkan prioritas strategis yang sangat tinggi sampai dengan yang terendah untuk keberlanjutan program pengembangan pengembangan pengelolaan irigasi partisipatif di Kabupaten Bogor. Strategi yang menjadi prioritas pertama adalah memprogramkan rencana pengelolaan jaringan irigasi secara partisipatif untuk peningkatan produksi dan peningkatan kesejahteraan petani dalam RPJMD Kabupaten Bogor dengan nilai TAS 8,34. Strategi yang menjadi prioritas kedua adalah memperkuat koordinasi antar stakeholder melalui fungsi koordinasi Komisi Irigasi dengan nilai TAS 8,14 . Strategi yang menjadi prioritas yang ketiga adalah meningkatkan dukungan Pemerintah Daerah Kabupaten Bogor untuk pembinaan petani agar bisa berpartisipasi dalam pengelolaan irigasi secara partisipatif dengan nilai TAS 7,93. 
Startegi yang menjadi prioritas keempat adalah mengelola jaringan irigasi secara partisipatif dengan dana yang ada dengan nilai TAS 7,71. Strattegi yang menjdi prioritas kelima adalah memperkuat kualitas SDM petani melalui pelatihan, bimbingan teknis, dan studi banding dengan nilai TAS 7,53. Strategi yang menjdi prioritas keenam adalah meningkatkan kesadaran petani dalam Pengelolaan Irigasi Partisipatif melalui sosialisasi dan pendampingan oleh tenaga pendamping yang proporsional dengan nilai TAS 6,89 .

Tabel 8. Hasil analisis QSPM dalam perumusan strategi peningkatan kinerja GP3A di Kabupaten Bogor.

\begin{tabular}{|c|l|c|c|}
\hline No & \multicolumn{1}{|c|}{ Alternatif Strategi } & $\begin{array}{c}\text { Nilai } \\
\text { TAS }\end{array}$ & Prioritas \\
\hline 1 & Mengelola jaringan irigasi secara partisipatif dengan dana yang ada & 7,71 & IV \\
\hline 2 & $\begin{array}{l}\text { Memprogramkan rencana pengelolaan jaringan irigasi secara partisipatif } \\
\text { untuk peningkatan produksi dan peningkatan kesejahteraan petani dalam } \\
\text { RPJMD Kabupaten Bogor }\end{array}$ & 8,34 & I \\
\hline 3 & $\begin{array}{l}\text { Memperkuat koordinasi antar stakeholder melalui fungsi koordinasi } \\
\text { Komisi Irigasi }\end{array}$ & 8,14 & II \\
\hline 4 & $\begin{array}{l}\text { Memperkuat kualitas SDM petani melalui pelatihan, bimbingan teknis, } \\
\text { dan studi banding }\end{array}$ & 7,53 & V \\
\hline 5 & $\begin{array}{l}\text { Meningkatkan dukungan Pemerintah Daerah Kabupaten Bogor untuk } \\
\text { pembinaan petani agar bisa berpartisipasi dalam pengelolaan irigasi } \\
\text { secara partisipatif }\end{array}$ & 7,93 & III \\
\hline 6 & $\begin{array}{l}\text { Meningkatkan kesadaran petani dalam Pengelolaan Irigasi Partisipatif } \\
\text { melalui sosialisasi dan pendampingan oleh tenaga pendamping yang } \\
\text { proporsional }\end{array}$ & 6,89 & VI \\
\hline
\end{tabular}

\section{RANCANGAN STRATEGI DAN PROGRAM}

Strategi Peningkatan Kinerja Gabungan Perkumpulan Petani Pemakai Air di Kabupaten Bogor merupakan langkah akhir dalam memberikan masukan alternatif strategi bagi pimpinan daerah dalam menetukan arah kebijakan strategi yang tepat guna, mutu, waktu dan biaya sehingga pelaksanaan kegiatan Water Resources And Irrigation Management Program (WISMP) yang telah diterapkan di Kabuapten Bogor mengenai pengelolaan irigasi partisipatif dapat terus berlanjut walau pun program tersebut telah selesai. Dalam rancangan pengembangan strategi program pengelolaan irigasi partisipatif yang berkelanjutan ini, juga memperhatikan visi dan misi Dinas Bina Marga dan Pengairan Kabupaten Bogor.

Strategi Peningkatan Kinerja Gabungan Perkumpulan Petani Pemakai Air (GP3A) di Kabupaten Bogor.

Strategi alternatif serta program pengembangan terbaik yang dapat dilaksanakan pemerintah daerah untuk mempertahankan tingkat kinerja dan partisipasi GP3A dalam rangka meningkatkan produktivitas fisik dan ekonomi pertanian beririgasi, berdasarkan hasil

Bobby Wahyudi, Yusman Syaukat, dan Lala M Kolopaking analisis kajian dengan memperhatikan visi dan misi Dinas Bina Marga dan Pengairan Kabupaten Bogor, maka didapatkan 6 (enam) rumusan strategi, yang terbagi dalam 3 (tiga) katagori rencana pembangunan daerah, antara lain yaitu :

A. Rencana Pembangunan Jangka Pendek

1. Memprogramkan rencana pengelolaan jaringan irigasi secara partisipatif untuk peningkatan produksi dan peningkatan kesejahteraan petani dalam RPJMD Kabupaten Bogor

2. Memperkuat koordinasi antar stakeholder melalui fungsi koordinasi Komisi Irigasi.

B. Rencana Pembangunan Jangka Menengah

1. Meningkatkan dukungan Pemerintah Daerah Kabupaten Bogor untuk pembinaan petani agar bisa berpartisipasi dalam pengelolaan irigasi secara partisipatif

2. Mengelola jaringan irigasi secara partisipatif dengan dana yang ada

C. Rencana Pembangunan Jangka Panjang

1. Memperkuat kualitas SDM petani melalui pelatihan, bimbingan teknis, dan studi banding

Strategi Peningkatan Kinerja Gabungan Perkumpulan Petani Pemakai Air (GP3A) Di Kabupatan Bogor 
2. Meningkatkan kesadaran petani dalam Pengelolaan Irigasi Partisipatif melalui sosialisasi dan pendampingan oleh tenaga pendamping yang proporsional

Rancangan program dan kegiatan ini disusun berdasarkan waktu pelaksanaan kegiatan pada tahun 2015 samapai dengan 2020, pada akhir tahun anggaran rancangan program tersebut diprioritaskan bisa tercapai. Rancangan program dan kegiatan mengenai
Pengembangan Program Pengelolaan Irigasi Partisipatif Yang Berkelanjutan yang berdasarkan pada Strategi Peningkatan Kinerja Gabungan Perkumpulan Petani Pemakai Air (GP3A) di Kabupaten Bogor PeriodeTahun 2015 - 2020 dapat dilihat pada Tabel Matriks Pengembangan Program Pengelolaan Irigasi Partisipatif Berkelanjutan di Kabupaten Bogor Periode Tahun 2015 - 2020.

Tabel 9. Matriks Pengembangan Program Pengelolaan Irigasi Partisipatif Yang Berkelanjutan di Kabupaten Bogor Periode Tahun 2015 - 2020.

\begin{tabular}{|c|c|c|c|c|c|c|c|c|c|}
\hline \multirow{2}{*}{ 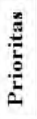 } & \multirow{2}{*}{ Strategi } & \multirow{2}{*}{ Program } & \multirow{2}{*}{ Kegiatan } & \multirow{2}{*}{$\begin{array}{l}\text { Perkiraan } \\
\text { Anggaran } \\
\text { (Rp) }\end{array}$} & \multicolumn{4}{|c|}{ Tahun Pelaksanaan } & \multirow{2}{*}{ Pelaksana } \\
\hline & & & & & I & II & III & IV & \\
\hline \multirow{3}{*}{1} & \multirow{3}{*}{$\begin{array}{l}\text { Memprogramkan rencana pengelolaan } \\
\text { jaringan irigasi secara partisipatif untuk } \\
\text { peningkatan produksi dan peningkatan } \\
\text { kesejahteraan petani dalam RPJMD } \\
\text { Kabupaten Bogor }\end{array}$} & \multirow{3}{*}{$\begin{array}{l}\text { Program Pengembangan Pengelolaan } \\
\text { Jaringan Irigasi Partisipatif }\end{array}$} & $\begin{array}{l}\text { Peningkatan Partisipatif Jaringan Irigasi } \\
\text { Sederhana Menjadi Semi Teknis }\end{array}$ & 50.000 .000 .000 & & & & & DBMP \\
\hline & & & Rehabilitasi Partisipatif Jaringan Irigasi & 35.000 .000 .000 & & & & & DBMP \\
\hline & & & $\begin{array}{l}\text { Pemeliharaan Partisipatif Jaringan } \\
\text { Irigasi }\end{array}$ & 5.000 .000 .000 & & & & & DBMP \\
\hline \multirow{2}{*}{2} & \multirow{2}{*}{$\begin{array}{l}\text { Memperkuat koordinasi antar } \\
\text { stakeholder melalui fungsi koordinasi } \\
\text { Komisi Irigasi }\end{array}$} & \multirow{2}{*}{$\begin{array}{l}\text { Program Pengutaan Kelembagaan } \\
\text { Komisi Irigasi }\end{array}$} & $\begin{array}{l}\text { Singkronisasi Data Pengelolaan Irigasi } \\
\text { Partisipatif }\end{array}$ & 125.000 .000 & & & & & $\begin{array}{l}\text { Bappeda, } \\
\text { DBMP, } \\
\text { Distanhut } \\
\text { (KOMIR) }\end{array}$ \\
\hline & & & $\begin{array}{l}\text { Koordinasi Pelaksanaan Kegiatan } \\
\text { Pengelolaan Irigasi Partisipatif }\end{array}$ & 85.000 .000 & & & & & $\begin{array}{l}\text { Bappeda, } \\
\text { DBMP, } \\
\text { Distanhut } \\
\text { (KOMIR) }\end{array}$ \\
\hline 3 & $\begin{array}{l}\text { Meningkatkan dukungan Pemerintah } \\
\text { Daerah Kabupaten Bogor untuk } \\
\text { pembinaan petani agar bisa } \\
\text { berpartisipasi dalam pengelolaan irigasi } \\
\text { secara partisipatif }\end{array}$ & $\begin{array}{l}\text { Program Peningkatan Kelembagaan } \\
\text { Petani }\end{array}$ & $\begin{array}{l}\text { Legalisasi P3A/GP3A/P3A melahui } \\
\text { SK Bupati dan Akta Notaris }\end{array}$ & 125.000 .000 & & & & & $\begin{array}{l}\text { Bappeda, } \\
\text { DBMP, } \\
\text { Distanhut } \\
\text { (KOMIR) }\end{array}$ \\
\hline 4 & $\begin{array}{l}\text { Mengelola jaringan irigasi secara } \\
\text { partisipatif dengan dana yang ada }\end{array}$ & $\begin{array}{l}\text { Program Penguatan Dana Pengelolaan } \\
\text { Irigasi }\end{array}$ & $\begin{array}{l}\text { Pembentukan Lembaga Pembiayaan } \\
\text { Pengelolaan Irigasi Partisipatif }\end{array}$ & 55.000 .000 & & & & & $\begin{array}{l}\text { Bappeda, } \\
\text { DBMP, } \\
\text { Distanhut } \\
\text { (KOMIR) }\end{array}$ \\
\hline \multirow{4}{*}{5} & \multirow{4}{*}{$\begin{array}{l}\text { Memperkuat kualitas SDM petani } \\
\text { melalui pelatihan, bimbingan teknis, dan } \\
\text { studi banding }\end{array}$} & \multirow{4}{*}{$\begin{array}{l}\text { Program Pembinaan dan Pelatihan } \\
\text { Petani }\end{array}$} & $\begin{array}{l}\text { Pelatihan Peningkatan Kapasitas } \\
\text { Kelembagaan }\end{array}$ & 375.000 .000 & & & & & Bappeda \\
\hline & & & $\begin{array}{l}\text { Bimtek dan Pelatihan Desain } \\
\text { Partisipatif }\end{array}$ & 375.000 .000 & & & & & DBMP \\
\hline & & & $\begin{array}{l}\text { Bimtek dan Pelatihan Konstruksi } \\
\text { Partisipatif }\end{array}$ & 375.000 .000 & & & & & DBMP \\
\hline & & & Studi Banding GP3A & 150.000 .000 & & & & & $\begin{array}{l}\text { Bappeda, } \\
\text { DBMP, } \\
\text { Distanhut }\end{array}$ \\
\hline \multirow{3}{*}{6} & \multirow{3}{*}{$\begin{array}{l}\text { Meningkatkan kesadaran petani dalam } \\
\text { Pengelolaan Irigasi Partisipatif melahui } \\
\text { sosialisasi dan pendampingan oleh } \\
\text { tenaga pendamping yang proporsional }\end{array}$} & \multirow{3}{*}{$\begin{array}{l}\text { Program Sosialisasi dan Pendampingan } \\
\text { Petani }\end{array}$} & $\begin{array}{l}\text { Sosialisasi Tentang Pengelolaan Irigasi } \\
\text { Partisipatif yang Berkelanjutan }\end{array}$ & 200.000 .000 & & & & & $\begin{array}{l}\text { Bappeda, } \\
\text { DBMP, } \\
\text { Distanhut } \\
\text { (KOMIR) }\end{array}$ \\
\hline & & & $\begin{array}{l}\text { Rekrutmen Tenaga Pendamping } \\
\text { Masyarakat Petani }\end{array}$ & 85.000 .000 & & & & & Bappeda \\
\hline & & & Pelatihan Traine Of Trainner bagi TPM & 150.000 .000 & & & & & Bappeda \\
\hline
\end{tabular}

\section{KESIMPULAN DAN SARAN}

\section{Kesimpulan}

Berdasarkan hasil kajian mengenai Strategi Peningkatan Kinerja Gabungan Bobby Wahyudi, Yusman Syaukat, dan Lala M Kolopaking
Perkumpulan Petani Pemakai Air (GP3A) di Kabupaten Bogor, didapat kesimpulan sebagai berikut :

1. Terlihat perbedaan kinerja antara GP3A 
WISMP dan GP3A Leubak yang bukan penerima Program WISMP. GP3A Mitra Tani setelah mendapatkan pembinaan dan pelatihan melalui Program WISMP menjadi lebih terarah dan teratur dalam kontribusi pengelolaan jaringan irigasi sehingga dapat meningkatkan jaringan irigasi sederhana menjadi irigasi teknis, mampu melakukan penyusunan dan mengusulkan Rencana Tata Tanam ditingkat GP3A kepada Pemerintah Daerah Kabupaten Bogor serta mampu meningkatkan hasil produksi rata-rata mencapai di atas $\pm 5 \mathrm{Ton} / \mathrm{Ha}$.

2. Berdasarkan analisis faktor internal dan eksternal, dalam rancangan Strategi Peningkatan Kinerja Gabungan Perkumpulan Petani Pemakai Air (GP3A) di Kabupaten Bogor menekankan pada strategi menggunakan kekuatan internal yang ada dengan memanfaatkan peluang eksternal, Hasil analisis QSPM didapatkan strategi yang menjadi prioritas adalah : a) Memprogramkan rencana pengelolaan jaringan irigasi secara partisipatif untuk peningkatan produksi dan peningkatan kesejahteraan petani dalam RPJMD Kabupaten Bogor; b) Memperkuat koordinasi antar stakeholder melalui fungsi koordinasi Komisi Irigasi.

\section{Saran}

Strategi Peningkatan Kinerja Gabungan Perkumpulan Petani Pemakai Air (GP3A) di Kabupaten Bogor didasarkan pada Aspek Tingkat Kinerja dan Kualitas Kinerja GP3A di Kabupaten Bogor dinilai perlu ada peningkatan kinerja. Faktor yang perlu ditingkatkan kinerjanya terdiri dari :

a. Dapat memberi rasa keadilan kepada anggota (hulu dan hilir) dalam pembagian air (B3),

b. Dapat memecahkan masalah, menekan/meredakan konflik pembagian air diantara anggota atau dengan pihak luar (B4),

c. Dapat meningkatkan dan mempertahankan intensitas tanaman pada tingkat yang tinggi dengan pengaturan air yang efisien (disamping aspek pertanian lain nonirigasi) (C1),

d. GP3A memiliki usaha ekonomi lain yang mandiri dan mendapat bantuan permodalan dari lembaga pembiayaan (D3)

Bobby Wahyudi, Yusman Syaukat, dan Lala M Kolopaking e. Adanya alokasi dana yang mencukupi untuk menunjang program pemberdayaan tersebut. (E2)

f. Adanya pendampingan petani dan unit pemberdayaan dengan sumber daya manusia yang handal ditingkat kabupaten/kota. (E3)

Untuk meningkatkan efektifitas pelaksanaan Strategi Peningkatan Kinerja Gabungan Perkumpulan Petani Pemakai Air (GP3A) di Kabupaten Bogor maka GP3A dapat memberikan argumentatif kepada Pemerintah Kabupaten Bogor dan Pemerintah Pusat untuk memberikan perhatian dan keterlibatan atas pentingnya keberlangsungan program pengelolaan irigasi partisipatif pada petani dengan meningkatkan pendapatan dan kesejahteraannya. Untuk itu saran yang diberikan pada :

\section{Pemerintah Kabupaten Bogor}

a. Menyiapkan anggaran yang lebih besar dari sebelumnya dari dana APBD untuk melakukan pembinaan dan pendampingan secara rutin terhadap GP3A;

b. Meningkatkan kerjasama dengan pihak akademisi dan lembaga penelitian untuk penerapan teknologi pertanian dan pengelolaan irigasi partisipatif.

c. Peningkatan pendapatan petani, melalui penanaman komoditas pertanian yang mempunyai nilai jual tinggi.

d. Peningkatan operasi pembagian air yang lebih baik sehingga kemerataan air meningkat

\section{Pemerintah Pusat}

a. Menempatkan prioritas kebijakan dan meningkatkan anggaran bantuan langsung masyarakat;

b. Melakukan pembinaan dan pelatihan kepada anggota GP3A penerima program WISMP secara intensif; dan

c. Melakukan monitoring dan evaluasi secara berkala pada anggota GP3A penerima program WISMP.

\section{Masyarakat Petani}

a. Turut berperan serta dalam menjaga keberlangsungan program pengelolaan irigasi partisipatif di perdesaan untuk kepentingan bersama sesuai dengan rencana.

b. Pengembangan penguatan program WISMP terhadap pengelolaan irigasi partisipatif yang berkelanjutan di Kabupaten Bogor sebaiknya dilakukan dengan pola comunity base Strategi Peningkatan Kinerja Gabungan 
development (pembangunan berbasis masyarakat) dengan prinsip partisipasi, edukasi dan local ownership sehingga lebih mensejahterkan masyarakat lokal. Perencanaan dan implementasi strategi dan program pengelolaan irigasi partisipatif yang berkelanjutan harus memperhatikan carrying capacity (daya dukung), capacity building (peningkatan kemampuan) lingkungan sehingga pengelolaan irigasi secara partisipatif yang di desain untuk Kabupaten Bogor akan sustainable (keberlanjutan), bertahan lama, semakin berkembang dan mandiri.

\section{DAFTAR PUSTAKA}

Adisasmita, Rahardjo. 2006. Pembangunan Pedesaan dan Perkotaan. Yokyakarta: Graha Ilmu

Akbar. (2011). Strategi Keberlanjutan Program Pengembangan Usaha Agribisnis Perdesaan (PUAP) (Kasus Kabupaten Karawang). Tesis. Institut Pertanian Bogor. Bogor.

Alwasilah, et al. (1996). Glossary of educational Assessment Term. Jakarta: Ministry of Education and Culture.

Artiningtyas. (2012). Analisis Tingkat Keberhasilan Pinjaman Bergulir PNPM Mandiri Perkotaan Berdasarkan Tingkat Konsumsi Masyarakat (Studi Kasus Kecamatan Petarukan Kabupaten Pemalang. Tesis. Universitas Indonesia. Jakarta.

Bappeda Kab. Bogor. (2011). Perda Nomor 16 Tahun 2011 tentang Rencana Pembangunan Jangka Menengah (RPJM) Daerah Kab. Bogor Tahun 2008 - 2013. Bogor.

Caesarion, Rio. (2011). Efektifitas Program Pengembangan Usaha Agribisnis Perdesaan (PUAP) Terhadap Kinerja Usaha Kecil di Kabupaten Lampung Selatan. Tesis. Institut Pertanian Bogor. Bogor.

Chandra, Rama. (2010). Analisis Pelaksanaan Program Keluarga Harapan (PKH) dan Dampaknya terhadap Peserta Program. Tesis. Universitas Indonesia. Jakarta.

Dokumen Jangka Panjang Menengah Program Penanggulangan Kemiskinan (PJM Pronangkis). Badan Keswadayaan Masyarakat (BKM). Bogor.

Bobby Wahyudi, Yusman Syaukat, dan Lala M Kolopaking
Ginting, J. (2004). Analisis Faktor Penyebab Pendapatan Petani Miskin di Kecamatan Deli Tua. Tesis. Universitas Sumatera Utara. Medan.

Guritno,Bambang dan Waridin. (2005). Pengaruh Persepsi Karyawan Mengenai Perilaku Kepemimpinan, Kepuasan Kerja dan Motivasi Terhadap Kinerja . Jurnal Riset Bisnis Indonesia Vol.1 No.1, p. 63-74.

Kabupaten Bogor Dalam Angka 2013, Badan Pusat Statistik Kabupaten Bogor.

Pedoman Teknis Pemberdayaan Perkumpulan Petani Pemakai Air (PT-PSP C 4. 22011). Jakarta. Direktorat Jenderal Sumber Daya Air. Kementerian Pekerjaan Umum.

Project Appraisal Document (PAD) Water Resources and Irrigation Sector Management Project I Buku 1. Jakarta. National Project Management Unit. Direktorat Jenderal Sumber Daya Air. Kementerian Pekerjaan Umum.

Project Implementation Program (PIP) Water Resources and Irrigation Sector Management Project I Buku 1. Jakarta. National Project Management Unit. Direktorat Jenderal Sumber Daya Air. Kementerian Pekerjaan Umum.

Project Management Manual (PMM) Water Resources and Irrigation Sector Management Project I Buku 1. Jakarta. National Project Management Unit. Direktorat Jenderal Sumber Daya Air. Kementerian Pekerjaan Umum

Ravallion et al. (2005). What Can ExParticipants Reveal about a Program's Impact?. The Journal of Human Resources, Vol. 40, No. 1. University of Wisconsin Press. www.jstor.org/stabel/4129571

Rangkuti, F. 2004. Analisis SWOT Teknik Membedah Kasus Bisnis. PT. Gramedia Pustaka Umum, Jakarta

Riadi, Alan. 2011. Pengaruh program pemberdayaan Gabungan Perkumpulan Petani Pemakai Air (GP3A) terhadap pendapatan petani anggota GP3A di Kecamatan Leuwiliang Kabupaten Bogor. Institut Pertanian Bogor.

Santosa, Hidayat, dan Indroyono. (2003). Evaluasi Dampak Program Penanggulangan Kemiskinan Bersasaran di Propinsi D.I. Jogjakarta.

Singarimbun, Masri. 1994. Metode Penelitian Survai. Jakarta: LPS3ES

Strategi Peningkatan Kinerja Gabungan Perkumpulan Petani Pemakai Air (GP3A) Di Kabupatan Bogor 
Suradisastra, K., W.K. Sejati, Y. Supriatna, dan D. Hidayat. 2002. Institutional Description of Balinese Subak. Jurnal Kajian dan Pengembangan pertanian, Vo. 21 No.1, 2002. Badan Kajian dan Pengembangan Pertanian, Departemen Pertanian. Jakarta.

Syahyuti, 2007. Strategi dan Tantangan dalam Pengembangan Gabungan Kelompoktani (GAPOKTAN) sebagai Kelembagaan Ekonomi di Pedesaan. Pusat Analisis Sosial Ekonomi dan Kebijakan Pertanian. Bogor

Water Resources and Irrigation Sector Management Project (WISMP) Main Report, 2004. Jakarta. National Project Management Unit. Direktorat Jenderal Sumber Daya Air. Kementerian Pekerjaan Umum. 